Man and Nature

L'homme et la nature

\title{
Ignatius Fessler's Attila: An Eighteenth-Century Historical Novelist's Reply to Schiller's Question "Was heisst und zu welchem Ende studiert man Universalgeschichte?"
}

\section{Linwood DeLong}

Volume 2, 1984

URI : https://id.erudit.org/iderudit/1011814ar

DOI : https://doi.org/10.7202/1011814ar

Aller au sommaire du numéro

Éditeur(s)

Canadian Society for Eighteenth-Century Studies / Société canadienne d'étude du dix-huitième siècle

ISSN

0824-3298 (imprimé)

1927-8810 (numérique)

Découvrir la revue

Citer cet article

DeLong, L. (1984). Ignatius Fessler's Attila: An Eighteenth-Century Historical Novelist's Reply to Schiller's Question "Was heisst und zu welchem Ende studiert man Universalgeschichte?". Man and Nature / L'homme et la nature, 2 , 83-91. https://doi.org/10.7202/1011814ar
Résumé de l'article

Qu'est-ce que l'histoire universelle et dans quel but peut-on l'étudier? Tant pour Fessier que pour Schiller, elle comporte la possibilité d'expliquer le progrès de l'espèce humaine à partir de ses débuts primitifs et permet aussi d'accélérer les progrès futurs. Le roman Attila de Fessier examine la compréhension que peut acquérir un grand individu des mouvements de l'histoire générale ainsi que sa capacité d'exercer une influence sur l'histoire.
Copyright (C Canadian Society for Eighteenth-Century Studies / Société canadienne d'étude du dix-huitième siècle, 1984
Ce document est protégé par la loi sur le droit d'auteur. L'utilisation des services d’Érudit (y compris la reproduction) est assujettie à sa politique d'utilisation que vous pouvez consulter en ligne.

https://apropos.erudit.org/fr/usagers/politique-dutilisation/ 


\title{
IGNATIUS FESSLER'S ATTILA: AN EIGHTEENTH-CENTURY HISTORICAL
}

\author{
NOVELIST'S REPLY TO SCHILLER'S QUESTION "WAS HEISST UND ZU
}

WELCHEM ENDE STUDIERT MAN UNIVERSALGESCHICHTE?"

\author{
Linwood DeLong
}

In 1789 Friedrich Schiller delivered his inaugural lecture at the University of Jena on the topic "Was heisst und $\mathrm{zu}$ welchem Ende studiert man Universalgeschichte?" The topic was hardly a new one, for by this time many eminent eighteenth-century historians had already published large volumes on this subject. Johann Christoph Gatterer had written his two-volume Handbuch der. Universalhistorie, 1 Isaac Iselin's Über die Geschichte der Menschheit had gone through several editions, ${ }^{2}$ and August Ludwig Schlözer, who had already published his Vorstellung seiner Universalhistorie, 3 was busy issuing his Weltgeschichte nach ihren Haupt-Theilen im Auszug und Zusammenhange. ${ }^{4}$ If one includes under the term "universal history" those historical works of preceding centuries that had systematized history according to the famous "four kingdoms of the world" mentioned in the Book of Daniel, then universal history as a concept extends very far back indeed.

However, Schiller's lecture documents a new approach to universal history that was emerging in the eighteenth century, not only a radical break with the aforementioned biblical scheme for organizing history, but more significantly the emergence of a linear view regarding the movement of history and the belief that mankind was individually and collectively applying his faculty of reason to the world around him and was achieving a measure of culture, political stability, and personal freedom that was unique in history and that was destined to increase as time continued. Thus in the early sections of his lecture Schiller reflects with pride not only on the achievements in agriculture, the arts, and religious thinking 
in the eighteenth century, but also on the general abolition of the barbaric impulses and practices of earlier generations in favour of a system of laws guaranteeing the equality of man and the peaceful co-existence of neighboring states. Universal history is, for Schiller, the attempt to explain as fully as possible how man developed from his primitive beginnings to the state of culture he enjoyed in the eighteenth century and also to show why mankind developed so unevenly in different parts of the globe.

In a subsequent publication, "Universalhistorische Übersicht der vornehmsten an den Kreuzzügen teilnehmenden Nationen," Schiller raised an interesting question: why did it take so long for mankind to develop from the initial high state of intellectual achievement and social harmony during Greek and Roman times to the higher state of development in modern times? In particular, he asked whether the Middle Ages, characterized as they were by such foolish phenomena as the Crusades or such despicable persons as Pope Gregory VII or Innocent IV, had really been necessary in the total scheme of things. Briefly, Schiller's answer was that an extended period of political instability had been necessary, in order to allow the slow process of intellectual and moral germination to take place. Premature political stability would have led to despotism, which would have prevented the widespread development of reason:

Ehe die Vernunft die Gesetze gefunden hätte, würde die Anarchie sich längst in Despotismus geendigt haben. Sollte die Vernunft also Zeit finden, die Gesetze sich zu geben, so musste die Gesetzlosigkeit verlängert werden, welches in dem Mittelalter geschehen ist. 5

Although this method of viewing history provides what Schiller certainly believed was a plausible explanation for the Dark Ages and the Middle Ages in the overall scheme of history, it does not offer guide-posts for evaluating the function of individual political, intellectual, or religious leaders from this period. One finds only passing references to great men, such as Socrates, or the somewhat evasive statement ( $p .23$ ) that even selfish, egotistical persons can unknowingly further noble causes. Schiller's "Universalhistorische Übersicht," written one year after his inaugural lecture, refers to the Vandals and the Huns as the two most frightening phenomena in history, "die zwei schrecklichsten Erscheinungen, welche die Geschichte aufweist" ( $p$. 102), but it says nothing of the leaders of these tribes. One can excuse schiller from a detailed discussion of individual leaders on the grounds that he was offering only a universal overview of large periods of history, but it should be noted that in 1790 schiller also published an essay entitled "Etwas über die erste Menschengesellschaft" in which he approaches universal history from the perspective of individual man, as opposed to tribes, political institutions, or cultural phenomena. Here he argues that man's expulsion from paradise was necessary for the subsequent development of his moral goodness. The fall of man was really the transition from man as an instinctual being--"ein Sklave des Naturtriebes"--to man as a thinking, reasoning being who will continue to develop his powers of intellect until, after many thousands of years, he reaches the stage of self-determination. Whereas Schiller's inaugural lecture is concerned with whole nations or races of people, his essay on the origins of human society, which is also concerned with universal history, focuses on an archetypal human family, to show how man first began to evolve his sense of moral responsibility. 
Thus, in two essays on the nature of history dating from approximately 1790, Schiller offers in effect two parallel explanations for the necessity of the development of man's intellectual capacities: a historical explanation, in the conventional sense of the term, showing how and why man as a constituent part of political and social organizations had to endure various forms of irrationality, in order to triumph over them later and achieve economic and political stability, and a philosophical explanation, showing how man as a thinking being had to develop his powers of intellect if he was to become morally free in his substantially improved political and cultural environment:

aus einem Paradies der Unwissenheit und Knechtschaft sollte [der Mensch] sich, wär es auch nach späten Jahrtausenden, zu einem Paradies der Erkenntnis und der Freiheit hinaufarbeiten, einem solchen nämlich, wo er dem moralischen Gesetze in seiner Brust ebenso unwandelbar gehorchen würde, als er anfangs dem Instinkte gedient hatte....6

It is not always clear, however, how Schiller proposes to reconcile these two approaches, in particular, to show how specific historical persons fit into either of his schemes of universal history. The titles of some of the other historical essays written by Schiller during this period, "Die Sendung Moses," "Die Gesetzgebung des Lykurgus und Solon," "Vorbericht zu den Denkwürdigkeiten des Herzogs von Sully," reveal that Schiller was keenly interested in the role of famous men in the processes of history. Several writers have noted that Schiller's more substantial histories, the Geschichte des dreissigjährigen Kriegs and the Geschichte des Abfalls der vereinigten Niederlande, frequently present political or military leaders as the decisive forces that influence the course of history. Yet in his inaugural lecture Schiller argues for the superiority of a universal historical perspective that focuses not on the life span of individuals but on a vast panorama of times and peoples. By encouraging human beings to see themselves as linked to the past and to the future, universal history "verbirgt... die Grenzen von Geburt und Tod, die das Leben des Menschen so eng und so drückend umschliessen, ... breitet ... optisch täuschend sein kurzes Dasein in einen unendlichen Raum aus und führt das Individuum unvermerkt in die Gattung hinuber" ( $p .22)$. Whereas Schiller's essay on the early stages of human existence focuses on man's need to achieve true moral goodness, his inaugural lecture refers to universal history as a cure for the "gemeine und kleine Ansicht moralischer Dinge" ( $p .22)$.

It is well known that Schiller's approach to history was influenced by the writings of Kant. The implications of this influence are worth noting, however. In Kant's two essays "Mutmasslicher Anfang der Menschengeschichte" and "Idee $\mathrm{zu}$ einer allgemeinen Geschichte in weltbürgerlicher Absicht" he also states that man had to abandon his initial state of dependence on instinct in order to develop his capacities of reason and, ultimately, his true destiny as a human being. Kant argues, however, that man will reach his intended goal not individually, but rather collectively as a member of, yet often in opposition to, the society of which he is a part. The ultimate destiny of man is therefore not simply the optimal development of his human capacities, but the evolution of a perfected form of government, which harmonizes all states and which alone provides the setting for man to develop his individual capacities: 
Am Menschen.... sollten sich diejenigen Naturanlagen, die auf den Gebrauch seiner Vernunft abgezielt sind, nur in der Gattung, nicht aber im Individuum vollständig entwickeln.

Man kann die Geschichte der Menschengattung im Grossen als die Vollziehung eines verborgenen Plans der Natur ansehen, um eine innerlichund zu diesem Zwecke auch äusserlich-vollkommene Staatsverfassung zu Stande zu bringen, als den einzigen Zustand, in welchem sie alle ihre Anlagen in der Menschheit völlig entwickeln kann. 7

Clearly Kant's philosophy of history is not particularly suited to explaining the role of individual politicians, military leaders or revolutionaries in the universal plan of history.

In 1794 Ignatius Fessler, a former Austrian Capuchin monk and professor of old Testament Languages at the University of Lwow, published his fourth historical novel, Attila König der Hunnen, in which he, like Schiller, applied Kantian philosophy to the study of history. Fessler's three previous historical novels, Marc-Aurel, Aristides und Themistocles, Matthias Corvinus, had all contained some assessment of the ethical stature of their main characters, but had frequently paid greater attention to the historical legacy of these men. 8 In his fourth novel Fessler particularly wished to focus on Attila's ethical stature, but in order to do this properly he felt he must also assess Attila's legacy in terms of universal political history. Fessler does not specifically refer to Schiller in his novel. However, his lengthy prefatory remarks, which criticize many eighteenth-century historians and explain Fessler's reasons for writing this novel, constitute a form of reply to the question posed by Schiller's inaugural lecture: what is universal history and why does one study it?

Fessler outlines two basic tasks for the historian: to record the facts that demonstrate the plan of history as postulated by philosophy, and to show how specific historical persons have demonstrated man's capacity to implement the dictates of the categorical imperative:

der höchste zweck aller menschengeschichte [besteht] darin, ... dass sie dem plane der Höchsten Vernunft in absicht auf das menschliche geschlecht und seiner ausbildung, welchen die teleologische urtheilskraft a priori vorzeichnet, in thatsachen a posteriori nachspührt; oder auch darin, dass sie das, von der Metaphysik gegebene characteristische merkmahl der menschheit empirisch zu erkennen gibt ...9

The first of these tasks, the verification of the ultimate plan of history, relates to ideas set forth in Schiller's inaugural lecture. In the closing sections of this lecture schiller states that a person of philosophical inclination who studies history may conclude that there is a teleological principle behind the events that are recorded. He may be inclined to detect not only cause and effect relationships but also indications of an ultimate meaning and purpose in the course of history. However, Schiller stops short of asserting that there is an ultimate purpose in the movement of history, for his historical methodology is strongly empirical, in spite 
of its speculative qualities. Thus he urges the writer of universal history to begin with the present and to follow history back to the origins of the present states of affairs, examining critically all facts, including those that dispel the notion of a telological principle in history.

Fessler, by contrast, regards the teleological movement of history as a given, a statement of reason, which must be empirically verified by the historian. He concurs implicitly with Kant's speculative approach to historiography that is founded on a philosophically, rather than empirically derived plan of history. Kant writes:

Ein philosophischer Versuch, die allgemeine Weltgeschichte nach einem Plane der Natur, der auf die vollkommene bürgerliche Vereinigung in der Menschengattung abziele, zu bearbeiten, muss als möglich und selbst für diese Naturabsicht beförderlich angesehen werden. 10

In his preface Fessler does not spell out his notion of the plan of history, but the opening paragraph of the body of the novel suggests that history is moving towards a state in which mankind will enjoy the full exercise of his reason. Summarizing European history from the fall of Rome to the eighteenth century Fessler writes: "nach dem verborgenen plane der natur sollte [der geist der wanderung und des raubes] die alte ordnung der dinge zerstören, um einer neuen platz zu machen, aus der sich die kraft und die herrschaft der vernunft in langsamen aber richtig abgemessenen fortschritten entwickeln konnte" (p. 31). Like Schiller, Fessler views the Crusades and the Protestant Reformation as key steps in the liberation and development of reason in the eighteenth century.

The second purpose that Fessler lays down for the historian--the investigation of whether and how consistently a historical person has followed the dictates of the categorical imperative--is again based on principles from Kant's philosophy. However, in order for the historian to assess the degree to which a historical person truly sought to govern himself by the categorical imperative, the historian must become a psychologist who can penetrate the thought processes of persons from the past. To this end Fessler distinguishes "pure history," or simple historical facts, from a higher form of historiography that considers human motivations. This higher form of historiography, with its liberal allowance for speculations concerning thoughts and emotions, is closely akin to historical fiction, although it should be noted that Fessler consulted historical source material extensively and that he asserted the accuracy of his speculations concerning Attila's thoughts. In keeping with eighteenth-century concepts of psychology, Fessler regards human behaviour as universally consistent. Thus he asserts confidently that historians can discover the thoughts of men who lived in a different age and culture because they can rely on the "gleichförmigkeit und unveränderliche einheit der naturgesetze und des menschlichen gemüthes" ( $p .14 n$ ).

We noted earlier, however, that Fessler addresses himself not simply to famous or important men of the past, but also to the total course of history, "[der] plan der Höchsten Vernunft in absicht auf das menschliche geschlecht und seiner ausbildung." Thus his criteria for judging a historical person also include the examination of the individual's role in furthering the optimal movement of history. It is not enough to consider on 
the one hand the general plan for the development of mankind, and on the other hand the motives or aspirations of some of the famous men of history. These approaches must be brought together. Fessler writes:

Endlich berechne [der Historiker]das verhältniss der handlungen des mannes nach seinen handlungsgrunden und den beabsichtigten folgen zu dem plane der Vorsehung in absicht auf das menschliche geschlecht und seine ausbildung(p. $24 n$ ).

Here Fessler's methodology can be criticized, for even if one can expect famous men of the past to adhere to a strict code of ethics, one can hardly demand that they divine the future and pattern their actions accordingly. Possibly Fessler was referring here to the obligation of every astute leader to make long-range plans. It should be noted, however, that Fessler is again assuming that there is a definite plan, devised by a higher power, for the development of mankind.

Summarizing our discussion so far we find that whereas Schiller in his essays on universal history is frequently concerned with the broad sweep of history, "das grosse Gemälde der Zeiten und Völker" and with the fate of mankind, rather than individual men, Fessler offers a historical method that considers the role of so-called great men of history from both an ethical and a universal historical point of view, a method that embodies not only aspects of Kant's concept of history but also fundamental principles from his ethics. According to Fessler, an historian not only explains the past; he also judges famous men from the past, selects those who were men of high ethical stature, and depicts them in such a way that his readers will emulate them.

Our discussion so far has concentrated on the preface to Fessler's novel. How, then, does he apply these theories to his own subject matter and what role does he accord to Attila? The answer to this question is rather complex, because Fessler's various objectives do not harmonize as easily as his prefatory remarks might suggest.

When viewed from an ethical perspective, Attila emerges in Fessler's novel as a great man. The opening chapters of the novel take Attila through a stormy youth, in which he is governed frequently by the "sturm seiner leidenschaften," to a stage of intellectual maturity where he can think abstractly, can make decisions on an intellectual, rather than an emotional basis, and where he can compensate for instinctual desires by his awareness of the deferment of gratification. Attila as an individual in fact goes through the basic stages of human development outlined by Kant or Schiller in their essays on the probable beginnings of civilization. As an adult, but also as a summation of the development of the primitive society of which he is the leader, Attila is capable of following the dictates of the categorical imperative. He regards his fellow tribesmen as ends in themselves, as persons who enjoy the same privileges that he enjoys, rather than as means to his ends.

But this in itself does not suffice to make Attila a great man, to explain his role for the universal historian, or to show whether his political goals coincided with the long-range plan of history. Fessler must introduce a broader historical perspective. He does so on several occasions, 
but particularly at the moment when Attila is deciding whether to invade Rome. He had been working systematically to destroy the Roman Empire, because of its moral corruptness, and had already destroyed its northern lines of defense. Attila's decision whether to continue his conquests of the Roman Empire is not simply an important moment in his career as leader of the Huns. It is for Fessler "[der] für alle folgende generationen Europa's, für das ganze menschengeschlecht ... entscheidende augenblick" (p. 275). Fessler is convinced that the emergence of an organized Church, the feudal system, the Crusades, and the Reformation were all necessary for the emergence of independency of reason, "Selbstthätigkeit der Vernunft," in his own age, and that none of this could have taken place if the Huns had established themselves in Europe by decisively defeating the Romans.

Attila was in fact assassinated before he could complete his plan to destroy the key cities of the Roman Empire. Yet Fessler argues that Attila was aware of the acute danger of executing his planned destruction of the Roman Empire and had decided to pull back. Thus in his novel the preservation of the Roman Empire at this point in history has two explanations: Attila's self-restraint, and the intervention by a higher power which led Attila's young bride to murder him. Fessler writes:

sie war das schreckliche werkzeug, durch welches eine höhere kraft Attila's grossem leben eine ende machte; weil das reich der Cäsarn untergehen, weil die neue hauptstadt der welt die noch übrigen der alten römischen geistesbildung und herrlichkeit einem würdigern zeitalter aufbewahren sollte ( $p .279)$.

Clearly Attila did not plan for his own assassination or for the dissolution of the Hun empire after his death. Yet when viewed from a universal historical perspective he appears not only as the first great leader of the various northern European tribes that were seeking to conquer the Romans, but also as a far-sighted thinker whose personal decisions coincided with the plan of destiny for mankind.

There are admittedly flaws in Fessler's novel. Quite apart from the fact that it is rather dry reading, it suffers from Fessler's inability to deal with those sources that suggested that Attila was a misogynist. Thus, in Fessler's account, Attila simultaneously despises mankind and adheres to the dictates of the categorical imperative. Furthermore, Fessler is not consistent in his historical evaluation of Attila. Although he recognizes the necessary destruction of the Hun Empire, before it supplanted the Roman Empire, he reverses his stance at the end of the novel and laments Attila's premature death before he was able to destroy the Roman Empire completely. Yet Fessler's contribution to historical thought in the eighteenth century should not be overlooked. 11

Whereas Schiller treated the Germanic invaders primarily as agents of destruction, Fessler focused on one famous leader of this period--Attila the Hun--and raised some fundamental questions. Is our evaluaion of the famous or infamous men of the past based purely on the record of their conquests, or have we also examined their ethical stature and their willingness to consider the future? Fessler's answer with respect to Attila was 
that Attila was not only a man of high ethical principles, but also a farsighted leader who came close to perceiving and implementing the long-range goal that history had accorded to his tribe. Fessler was also suggesting that even in the so-called Dark Ages there were men who as individuals developed their human intellectual potential to a high degree and who could serve as models of humanity for a so-called "enlightened age" that evolved thirteen hundred years later.

University of Winnipeg

NOTES

1 Johann Christoph Gatterer, Handbuch der Universalhistorie nach ihrem gesamten Umfange von Erschaffung der Welt, bis zum Ursprunge der meisten heutigen Reiche und Staaten, 2 vols. (Göttingen, 1764-1765).

2 Isaac Iselin, über die Geschichte der Menschheit, 4th ed. (Basel, 1779).

3 August Ludwig Schlözer, Vorstellung seiner Universalhistorie (Göttingen, 1772).

4 Schlözer, Weltgeschichte nach ihren Haupt-Theilen im Auszug und Zusammenhange (Göttingen, 1785-1789).

5 Friedrich Schiller, "Universalhistorische Übersicht der vornehmsten an den Kreuzzügen teilnehmenden Nationen, ihrer Staatsverfassung, Religionsbegriffe, Sitten, Beschäftigungen, Meinungen, und Gebräuche," dtv-Gesamtausgabe, ed. Herbert Göpfert (Munich, 1966), vol. 15, p. 10ln. All references to Schiller's essays on history are to this edition.

Schiller, "Etwas über die erste Menschengesellschaft nach dem Leitfaden der mosaischen Urkunde," dtv-Gesamtausgabe, vol. 15, p. 25.

7 Immanuel Kant, "Idee $\mathrm{zu}$ einer allgemeinen Geschichte in weltbürgerlicher Absicht," Gesammelte Schriften, ed. Preussische Akademie der Wissenschaften, I, 8(Berlin, 1923), Zweiter Satz, p. 18, Achter Satz, p. 27.

8 For a more detailed discussion of these novels see Linwood Delong, "Ignatius Aurelius Fessler as a Historical Novelist: His Theory and Practice," Diss. University of Toronto, 1979, pp. 235-324. For detailed biographical information on Fessler see Peter F. Barton, Ignatius Aurelius Fessler: Vom Barockkatholizismus zur Erweckungsbewegung 
(Vienna, 1969) and P.F. Barton, Jesuiten, Jansanisten, Josephiner: Eine Fallstudie zur frühen Toleranzzeit: Der Fall Innocentius Fessler, Studien und Texte zur Kirchengeschichte und Geschichte. Zweite Reihe, 4 (Vienna, 1978).

9 Ignatius Aurelius Fessler, Attila König der Hunnen (Breslau, 1794), p. $14 \mathrm{n}$. All references to Attila are to this first edition of the novel.

10 Kant, "Idee $\mathrm{zu}$ einer allgemeinen Geschichte in weltbürgerlicher Absicht," Neunter Satz, p. 29.

11 Fessler later turned from writing historical fiction to writing conventional historical treatises. He eventually published a 10-volume history of Hungary, Die Geschichten der Ungern (Leipzig, 1815-1825). 